\title{
Diffusely adherent Escherichia coli strains isolated from children and adults constitute two different populations
}

Rosane Mansan-Almeida, Alex Leite Pereira* and Loreny Gimenes Giugliano

\begin{abstract}
Background: Diffusely adherent Escherichia coli (DAEC) have been considered a diarrheagenic category of E. coli for which several potential virulence factors have been described in the last few years. Despite this, epidemiological studies involving DAEC have shown inconsistent results. In this work, two different collections of DAEC possessing Afa/Dr genes, from children and adults, were studied regarding characteristics potentially associated to virulence.

Results: DAEC strains were recovered in similar frequencies from diarrheic and asymptomatic children, and more frequently from adults with diarrhea $(P<0.01)$ than from asymptomatic adults. Association with diarrhea $(P<0.05)$ was found for SAT-positive strains recovered from children and for curli-positive strains recovered from adults. Mixed biofilms involving DAEC and a Citrobacter freundii strain have shown an improved ability to form biofilms in relation to the monocultures. Control strains have shown a greater diversity of Afa/Dr adhesins and higher frequencies of cellulose, TTSS, biofilm formation and induction of IL-8 secretion than strains from cases of diarrhea in children.
\end{abstract}

Conclusions: DAEC strains possessing Afa/Dr genes isolated from children and adults represent two different bacterial populations. DAEC strains carrying genes associated to virulence can be found as part of the normal microbiota present in asymptomatic children.

Keywords: Diffusely adherent Escherichia coli, Diarrhea, Microbiota

\section{Background}

Escherichia coli is one of the most frequent causes of diarrhea in children in developing countries. However, characterization of truly diarrheagenic groups or strains can be a complex task because this species is one of the first colonizers of the human gut. Moreover, wild strains exhibit great genetic plasticity and heterogeneity [1].

Diffusely adherent Escherichia coli have been considered a diarrheagenic group of $E$. coli (DEC). They are characterized by the diffuse adherence pattern on cultured epithelial cells HeLa or HEp-2 [2]. Approximately $75 \%$ of DAEC harbor adhesins from the Afa/Dr family, responsible for this adherence phenotype [3]. Since Germani et al. [4] demonstrated that, among DAEC strains, only those that were positive to daaC probe - that recognize a conserved region from $\mathrm{Afa} / \mathrm{Dr}$ adhesins operons - were found in

\footnotetext{
* Correspondence: alexpereira@unb.br

Laboratório de Microbiologia, Departamento de Biologia Celular, Universidade de Brasília, Brasília, DF 70910-900, Brazil
}

higher frequency in diarrheic patients than asymptomatic controls, much attention has been given to DAEC strains possessing Afa/Dr adhesins.

The adhesins of Afa/Dr family have been implicated in DAEC pathogenesis. They include adhesins found in uropathogenic strains, like the $\mathrm{Dr}$ adhesin, in addition to AfaE-I, AfaE-II, AfaE-III, AfaE-V and F1845, which occur in diarrheagenic DAEC strains [5]. They recognize DAF (Decay Accelerating factor, CD55) and some of them also recognize CEACAMs (CEA-related molecules) as receptors [3]. The receptor is recruited around the bacteria after binding to the host cell [6,7]. The binding of strains expressing F1845 or Dr adhesin can promote the dismantling of the actin network in intestinal cells, causing elongation of microvilli $[8,9]$ and redistribution of cytoskeletonassociated proteins in HeLa cells [10].

However, in some studies, DAEC Afa/ $\mathrm{Dr}^{+}$strains are isolated from cases of diarrhea and controls in similar frequencies [11,12], suggesting that additional factors 
may be necessary to trigger disease. In recent years, some of these potential virulence factors have been described. In addition, some studies have implicated DAEC strains as diarrheal agents only in children older than six months, depending on the study, and in adults. [4,13-19].

Evidence of a type three secretion system (TTSS) in DAEC Afa/ $\mathrm{Dr}^{+}$isolated from cases of diarrhea in children has been demonstrated by Kyaw et al. [20]. The concomitant presence of $\mathrm{Afa} / \mathrm{Dr}$ adhesins in these strains suggests that an adhesin-receptor-effector protein mechanism, similar to the one seen in EPEC (enteropathogenic E. coli), might occur in DAEC. After adhesion and intimate contact, EPEC strains use TTSS to inject effector proteins into the host cell, inducing lesions in the cytoskeleton.

Taddei et al. [21] reported the presence of the secreted autotransporter toxin (SAT) belonging to the family of serine protease autotransporters of Enterobacteriaceae (SPATE) in DAEC strains isolated from diarrhea. Guignot et al. [22] have demonstrated that SAT is able to cause lesions on tight junctions of epithelial cells, which in turn may lead to an increase in their permeability. They also found SAT more frequently in DAEC strains isolated from diarrheic children than from asymptomatic subjects, corroborating the role of SAT as a virulence factor.

DAEC strains have demonstrated pro-inflammatory effects, related to an increased secretion of interleukin-8 by epithelial cells. In T84 cells infected by wild-type strains, basolateral secretion of IL-8 promotes transmigration of polymorphonuclear leukocytes (PMNLs) across the epithelial monolayer [23]. The transmigrated PMNs increase apoptotic rates and reduce phagocytic activity [24] which can contribute to maintain the inflammatory response without eliminating the pathogen. Some studies $[18,25]$ have found that the ability of increasing IL-8 secretion in epithelial cells by DAEC strains was associated with diarrhea in children.

One characteristic that has not been studied in DAEC is the ability to form biofilms. Although biofilm formation is a widespread phenomenon in bacteria, only recently has the importance of biofilms as a pathogenic factor been demonstrated for E. coli, such as in atypical EPEC strains [26] and in enteroaggregative E. coli (EAEC). The latter have biofilm formation as the only consensual virulence factor [27].

In a previous study performed in this laboratory [28], it was found that EAEC biofilms could be enhanced by interaction with a Citrobacter freundii strain isolated concomitantly with EAEC from a diarrheic child. These mixed biofilms seem to be mediated by $\mathrm{F}$ pili. Aside from their role in conjugation, $\mathrm{F}$ pili have been considered important in establishing $E$. coli biofilms, in addition to other components like curli and cellulose [29,30]. In this work, we employed a $C$. freundii strain to assess the capacity of DAEC strains to form biofilms alone or with other bacteria, as well as to investigate the occurrence of synergistic effects as seen for EAEC strains. Furthermore, we analyzed characteristics potentially associated with virulence or related to biofilm formation, such as Afa/Dr adhesins, SAT toxin, TTSS, F pili, curli, cellulose and stimulus of IL8 secretion by epithelial cells. The aim of this work is to study the overall profile of DAEC strains isolated from children and adults, both from cases of diarrhea and controls, thereby performing a systematic study of DAEC.

\section{Results}

\section{Prevalence of DAEC strains}

A total of 1,253 E. coli isolates recovered from stool samples of 127 cases of diarrhea in children and 127 asymptomatic controls were examined for the presence of genes belonging to the conserved region of the afa operons (afaB$\mathrm{C})$, which encode the Afa/Dr family of adhesins. Since EPEC strains occasionally have these adhesins, the presence of eae gene, typical of this category, was also investigated. One hundred and eighteen $a f a B-C$ positive isolates tested negative for eae. In adhesion tests, most strains (95/118 $80.5 \%)$ showed diffuse adherence. Nine strains (7.7\%) were non-adherent and one strain $(0.8 \%)$ adhered in an unclassified pattern. These strains were excluded from the study. Despite the fact that other thirteen strains (11\%) caused cell detachment, diffusely adhering bacteria could be detected in remaining cells, and these strains were included in the sample. Thus, one hundred and eight strains, including 50 from cases of diarrhea and 58 from controls, were considered as DAEC possessing Afa/Dr genes (Table 1).

The prevalence of DAEC possessing Afa/Dr genes in cases of diarrhea in children and their controls was similar (Table 1). DAEC strains were detected in 21 of the 127 cases of diarrhea in children (16.5\%), and in 25 of 127 asymptomatic controls (19.6\%). Association with diarrhea was not found even when the children were stratified by age (comparing children younger or older than six months, as well as 12 months).

Furthermore, DAEC strains possessing Afa/Dr genes were recovered from 27 out of $143(18.8 \%)$ cases of diarrhea in adults, and from five out of 119 (4.2\%) healthy subjects (Table 1). All strains showed diffuse adherence in adhesion tests. Consequently, DAEC strains were found in higher prevalence in cases of diarrhea in adults $(\mathrm{P}<0.01)$. Twenty seven DAEC strains were obtained from adults with diarrhea and fifteen from asymptomatic adults (Table 1).

\section{Diversity of Afa/Dr adhesins in strains from children and adults}

Some molecular studies indicate the involvement of Afa/Dr adhesins in DAEC-induced pathogenesis [8-10]. We 
Table 1 DAEC strains possessing Afa/Dr genes detected among patients and controls

\begin{tabular}{|c|c|c|c|c|c|}
\hline \multirow[t]{2}{*}{ Group } & \multicolumn{2}{|c|}{ Children } & \multicolumn{2}{|c|}{ Adults } & \multirow[t]{2}{*}{ Total } \\
\hline & Diarrhea & Control & Diarrhea & Control & \\
\hline Number of subjects enrolled & 127 & 127 & 143 & 119 & 516 \\
\hline Number of subjects harboring DAEC & $21(16.5 \%)$ & $25(19.6 \%)$ & $27^{*}(18.9 \%)$ & $5^{*}(4.2 \%)$ & $78(15.7 \%)$ \\
\hline Number of DAEC strains isolated in each group & 50 & 58 & 27 & 15 & 150 \\
\hline
\end{tabular}

$*(P<0.01)$

examined their distribution in strains isolated from cases of diarrhea and asymptomatic controls. Different members of the Afa/Dr family were detected using specific primers for the adhesin-encoded genes ( $a f a \mathrm{E})$. Their distribution is shown in Table 2.

In 20\% (30/150) of afaB-C-positive strains, the adhesin gene could not be identified. These strains with indeterminate $a f a \mathrm{E}$ were referred to as "afa-X".

Strains isolated from children and adults exhibited a very different distribution of $\mathrm{Afa} / \mathrm{Dr}$ adhesin encoding genes. The $a f a E-1$ gene was a notable exception, being similarly distributed for all groups. It was also the most frequent gene.

Strains isolated from children showed great diversity of adhesins. More than one type of Afa/Dr adhesins were detected in $21.3 \%(23 / 108)$ of strains isolated from children, and in $29.3 \%$ (17/58) of strains isolated from asymptomatic children. All genetic combinations involve $a f a E-1$ or daaE. The afaE-1/afaE-2 association was found only in diarrheagenic strains $(\mathrm{P}<0.05)$. The F1845 encoding gene was only found in strains isolated from children, especially in control strains.
Strains isolated from adults showed a low variability of $a f a \mathrm{E}$ genes. Prevalence of $a f a-\mathrm{X}$ was higher $(\mathrm{P}<0.01)$ in cases of diarrhea, while prevalence of $a f a \mathrm{E}-5$ was higher in controls $(\mathrm{P}<0.01)$. Neither the daaE gene nor associations between two types of adhesins were detected in strains from adults.

\section{Distribution of virulence factors}

DAEC strains were examined regarding characteristics associated with virulence. The percentage of strains carrying virulence genes or possessing phenotypic characteristics associated to biofilm formation is summarized in Table 3.

As we were interested in investigating a possible role for F pili in the establishment of DAEC biofilms, we performed PCR assays to detect the traA gene encoding pilin F. traA-positive DAEC strains were frequently detected in all groups of tested strains.

The production of cellulose and curli - common components of $E$. coli biofilms - was investigated. Only one strain isolated from adults tested positive for cellulose

Table $2 \mathrm{Afa} / \mathrm{Dr}$ adhesins distribution in DAEC strains isolated from cases of diarrhea and asymptomatic controls

\begin{tabular}{|c|c|c|c|c|c|c|}
\hline \multirow[b]{4}{*}{$a f a E$} & \multicolumn{6}{|c|}{ Strains isolated from } \\
\hline & \multicolumn{3}{|c|}{ Children } & \multicolumn{3}{|c|}{ Adults } \\
\hline & Diarrhea & Control & & Diarrhea & Control & \\
\hline & $\mathrm{N}(\%)$ & $\mathrm{N}(\%)$ & Total & $\mathrm{N}(\%)$ & $\mathrm{N}(\%)$ & Total \\
\hline 1 & $22(44)$ & $19(32.8)$ & $41(38)$ & $12(44.4)$ & $5(33.3)$ & $17(40.5)$ \\
\hline 2 & $5(10)$ & $3(5.2)$ & $8(7.4)$ & $1(3.7)$ & $2(13.3)$ & $3(7.1)$ \\
\hline 3 & $1(2)$ & $1(1.7)$ & $2(1.8)$ & $2(7.4)$ & $1(6.7)$ & $3(7.1)$ \\
\hline 5 & $1(2)$ & $2(3.5)$ & $3(2.8)$ & $1(3.7)^{\mathrm{a}}$ & $7(46.7)^{a}$ & $8(19)$ \\
\hline$x$ & $12(24)$ & $7(12)$ & $19(17.6)$ & $11(40.7)^{\mathrm{a}}$ & $0^{\mathrm{a}}$ & $11(40.7)$ \\
\hline daaE & $3(6)$ & $9(15.5)$ & $12(11)$ & 0 & 0 & 0 \\
\hline $1+2$ & $5(10)$ & 0 & $5(4.6)$ & 0 & 0 & 0 \\
\hline $1+3$ & 0 & $1(1.7)$ & $1(0.9)$ & 0 & 0 & 0 \\
\hline $1+5$ & 0 & $6(10.3)$ & $6(5.1)$ & 0 & 0 & 0 \\
\hline $1+d a a E$ & $1(2)$ & $5(8.6)$ & $6(5.1)$ & 0 & 0 & 0 \\
\hline $1+2+d a a E$ & 0 & $1(1.7)$ & $1(0.9)$ & 0 & 0 & 0 \\
\hline $2+d a a E$ & 0 & $2(3.5)$ & $2(1.8)$ & 0 & 0 & 0 \\
\hline $5+d a a E$ & 0 & $2(3.5)$ & $2(1.8)$ & 0 & 0 & 0 \\
\hline Total & 50 & 58 & 108 & 27 & 15 & 42 \\
\hline
\end{tabular}

${ }^{\mathrm{a}} \mathrm{P}<0.05$ (cases $\mathrm{x}$ control). 
Table 3 Characteristics associated to virulence in DAEC strains possessing Afa/Dr genes isolated from children and adults

\begin{tabular}{ccccc}
\hline & \multicolumn{4}{c}{ Strains isolated from N(\%) } \\
\cline { 2 - 5 } Characteristic & \multicolumn{2}{c}{ Children } & \multicolumn{2}{c}{ Adults } \\
\cline { 2 - 5 } Diarrhea & Control & Diarrhea & Control \\
\hline traA & $45(90)$ & $47(81)$ & $19(70.3)$ & $13(86.6)$ \\
Cellulose & $5(10)$ & $17(29.3)$ & $1(3.7)$ & 0 \\
Curli & $31(62)$ & $39(67.2)$ & $16(59.2)^{\mathrm{a}}$ & $1(6.7)^{\mathrm{a}}$ \\
sat & $23(46)$ & $11(18.9)$ & $18(66.7)$ & $13(86.6)$ \\
TTSS & $3(6)$ & $30(51.7)$ & $1(3.7)$ & 0 \\
Motility & $45(90)$ & $55(94.8)$ & $19(70.3)$ & $14(93.3)$ \\
IL-8 secretion & $14(28)$ & $31(53.4)$ & $0^{\mathrm{a}}$ & $4(26.6)^{\mathrm{a}}$ \\
Total & 50 & 58 & 27 & 15 \\
\hline aP $<0.05$ (cases $\times$ control) & & & &
\end{tabular}

${ }^{\mathrm{a}} \mathrm{P}<0.05$ (cases $\mathrm{x}$ control).

production. In strains from children, the prevalence of cellulose production was higher $(\mathrm{P}<0.05)$ among control strains $(29.3 \%$ - $17 / 58)$ than in those recovered from diarrhea $(10 \%-5 / 50)$.

Curli-positive strains were isolated in similar frequencies from diarrheic $(62 \%-31 / 50)$ and asymptomatic $(67.2 \%$ $39 / 58)$ children. In contrast, in strains from adults, expression of curli was higher $(\mathrm{P}<0.05)$ in strains from diarrhea $(59.2 \%-16 / 27)$ than from controls $(6.7 \%-1 / 15)$.

The gene that codes for the SAT toxin was often found in strains from adults, both diarrheic $(66.7 \%-18 / 27)$ and asymptomatic $(86.6 \%-13 / 15)$. By contrast, in strains from children, the sat gene was found in higher prevalence $(\mathrm{P}<0.05)$ in cases of diarrhea $(46 \%-23 / 50)$ than in controls $(18.9 \%-11 / 58)$, corroborating the hypothesis of its involvement in diarrhea induced by DAEC in children.

We also investigated the occurrence of the escV and escJ genes that are part of the type three secretion system in DAEC strains. When analyzing strains isolated from adults, these genes were found in only one strain, isolated from diarrhea (3.7\%). Unexpectedly, 51.7\% (30/58) of the strains isolated from asymptomatic children were positive for $e s c V$ or escJ, while they were found in only $6 \%(3 / 50)$ of strains from children with diarrhea $(\mathrm{P}<0.05)$.

When the motility of DAEC strains on a semi-solid agar medium was investigated, it was found that most strains $(88.6 \%)$ had swimming ability, regardless of their origin.

When the strains were tested for IL-8 secretion, $53.4 \%$ $(31 / 58)$ of control strains and $28 \%(14 / 50)$ of strains from diarrhea in children were able to stimulate secretion by HeLa cells $(\mathrm{P}<0.01)$. When analyzing adults, $26.6 \%(4 / 15)$ of strains isolated from asymptomatic control subjects stimulated IL-8 production. All IL-8 stimulating strains isolated from adults came from a single case, and probably represent a clone. Positive strains were not detected in strains isolated from diarrheic adults. The average level of IL- 8 secretion by DAECstimulated HeLa cells was $60 \mathrm{pg} / \mathrm{mL}$, reaching a maximum of $350 \mathrm{pg} / \mathrm{mL}$. Most strains from both children and adults showed low levels of IL-8 secretion. IL- 8 secretion was not detected in non infected HeLa cells or in cells infected with E. coli C600.

Ability of stimulate IL-8 secretion in HeLa cells was not associated to motility, afaE type or other characteristic examined in this work.

\section{Classical EPEC serogroups}

All strains were screened for classical EPEC serogroups. They were detected in $30.5 \%$ (33/108) of DAEC strains isolated from children. We observed serogroups O86, O158, O142 and O127. Serogroup O86 was found most frequently, both in diarrhea and control strains (Table 4). Distribution of genotypic and phenotypic characteristics was similar in DAEC strains belonging to both EPEC and non-EPEC serogroups. Serogroups associated to EPEC were not detected in strains isolated from adults.

\section{Biofilms}

Most DAEC strains were not able to form biofilms as pure cultures. Tests carried out with DAEC strains isolated from children showed that $88.9 \%(96 / 108)$ of them were unable to form biofilms under the studied conditions; 11\% (12/108) formed weak biofilms (Figure 1A). The frequency of strains from children that form biofilms was greater $(\mathrm{P}<0.01)$ in control $(18.9 \%-11 / 58)$ than in cases of diarrhea $(2 \%-1 / 50)$.

Tests performed with DAEC strains isolated from adults showed that $73.8 \%$ (31/42) did not form biofilms. Eleven strains (26.2\%) formed biofilms (Figure 1C). The frequency of biofilm formation did not differ between cases $(25.9 \%-7 / 27)$ and control $(26.6 \%-4 / 15)$ strains.

The frequency of DAEC strains able to form biofilms was greater $(\mathrm{P}<0.05)$ among strains isolated from adults $(26.2 \%-11 / 42)$ than from children $(11 \%-12 / 108)$.

\section{Mixed biofilms}

In order to evaluate the effect of bacterial combinations on biofilm formation, mixed biofilm assays were

Table 4 Classical EPEC serogroups found in DAEC possessing Afa/Dr genes isolated from children

\begin{tabular}{ccccccc}
\hline Serogroups & $\mathbf{0 8 6}$ & $\mathbf{0 1 2 7}$ & $\mathbf{0 1 4 2}$ & $\mathbf{0 1 5 8}$ & Non-EPEC \\
& \multicolumn{5}{c}{$\mathbf{N}(\%)$} & \\
\hline Diarrhea & $13(26)$ & 0 & $1(2)$ & $5(10)$ & $31(62)$ & 50 \\
Control & $7(12)$ & $2(3.4)$ & 0 & $5(8.6)$ & $44(75.8)$ & 58 \\
Total & $20(18.5)$ & $2(1.8)$ & $1(0.9)$ & $10(9.2)$ & $75(69.5)$ & 108 \\
\hline
\end{tabular}




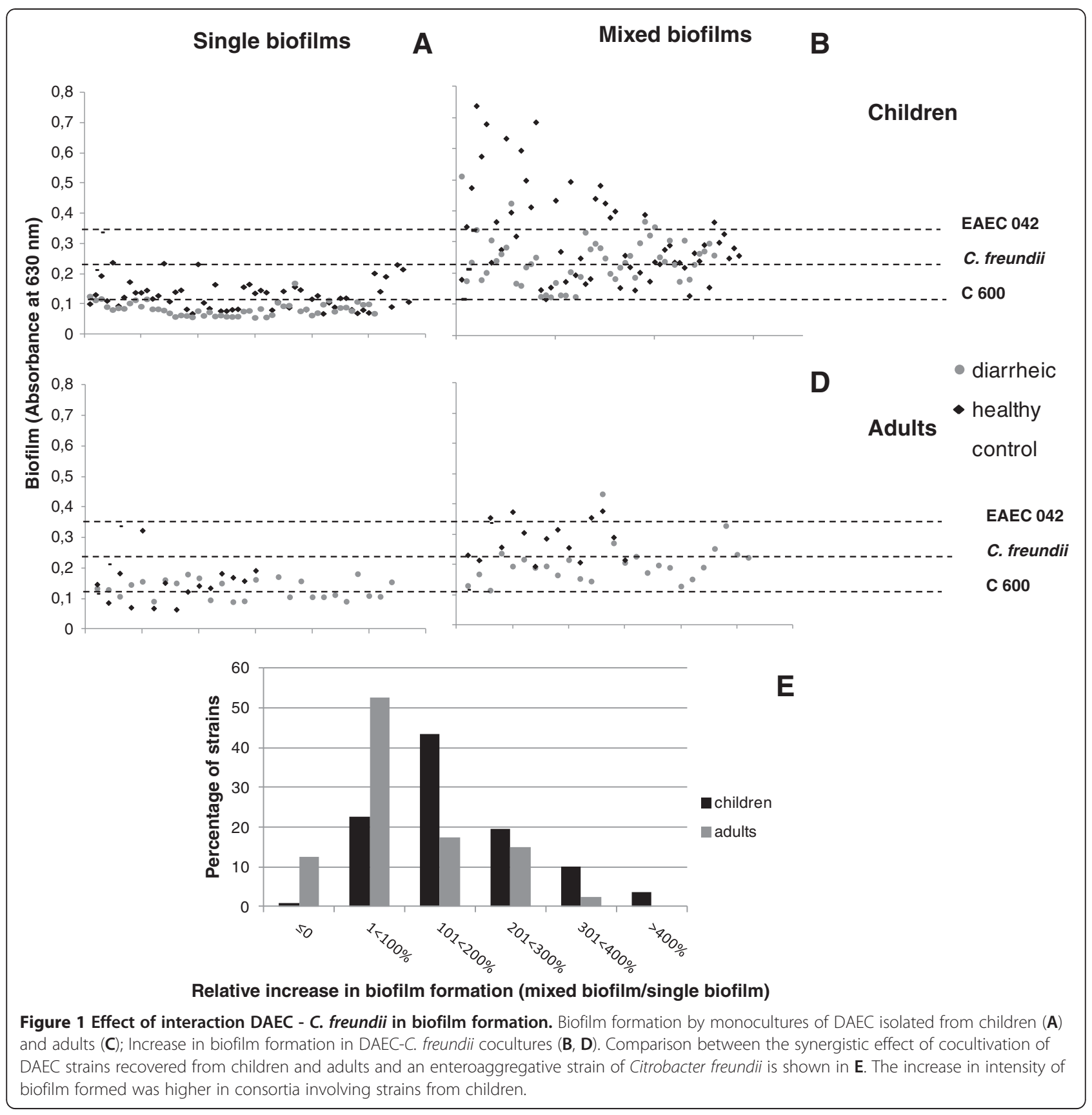

conducted using cocultures of DAEC and C. freundii strain Cf 205, which forms weak biofilms when in monoculture. Mixed biofilm formation was observed in $83 \%$ (90/108) of consortia involving strains from children. In $30 \%$ (27/90) of consortia, weak biofilms were formed, while 70\% (63/90) of cocultures formed strong biofilms, indicating a synergistic effect of the DAEC- C. freundii association (Figure 1B). Strong biofilms were more frequent $(\mathrm{P}<0.05)$ in consortia involving strains from asymptomatic children $(67.2 \%$ - 39/58) than in those involving cases of diarrhea $(48 \%-24 / 50)$.
Biofilm formation was observed in $80.9 \%$ (34/42) of consortia involving strains from adults. Twenty-three consortia $(67.6 \%$ - 23/34) formed weak biofilms, and $32.3 \%$ (11/34) formed strong biofilms (Figure 1D). When analyzing the frequency of overall biofilm formation, we found no statistically significant difference in strains from cases $(81.5 \%$ - 22/27) and control (80\% - 12/15).

To verify the relative increase of intensity in mixed biofilm formation, the optical density (OD) observed in each coculture was compared to the OD obtained by the respective DAEC strain in monoculture. The effect of 
the DAEC - C. freundii association was more pronounced in strains from children. The cocultures involving strains from children showed increases in mixed biofilm formation between $101 \%$ and $200 \%$. For most strains from adults, the increase was less than $100 \%$ (Figure 1E). Furthermore, the maximum increase in intensity observed for adult strains was three-fold while in strains from children it reached six-fold.

\section{Adhesion to HeLa cells}

To evaluate whether the increase in biofilm formation by DAEC - C. freundii consortia was associated to an increased adhesion to epithelial cells, mixed adhesion tests were performed. Light microscopy showed that the adhesion to HeLa cells developed by DAEC - Cf 205 associations was greater than that supported by each strain separately (Figure 2). An increment in bacterial adhesion was observed when the experiments were repeated with several DAEC $-C$. freundii pairs that had shown increased biofilms.

\section{Effect of zinc on mixed biofilms}

In order to evaluate the impact of zinc on mixed biofilm formation and, consequently, the role of putative $\mathrm{F}$ pili, biofilm assays were performed by adding zinc to the medium. In strains from children, $57.7 \%$ (52/90) of DAEC - C. freundii consortia had biofilms reduced or abolished when zinc was added. We also observed reduction in $50 \%$ of single biofilms $(6 / 12)$ in the presence of zinc. Similarly, reduction was observed in $52.9 \%$ $(18 / 34)$ of mixed biofilms and $54.5 \%(6 / 11)$ of single biofilms with DAEC strains from adults.

Some mixed biofilms reduced by zinc involving traA positive DAEC strains were submitted to electronic microscopy. The analysis revealed thick, non-bundle forming pili mediating cell-to-cell adherence and adhesion to an abiotic surface (Figure 3A and C). Large amounts of matrix, but not pili, were observed in biofilms that were not affected by $0.25 \mathrm{mM}$ of zinc (3D). Fibers resembling curli were occasionally observed as part of biofilms in addition to pili (3A).

\section{Discussion}

The human gut is colonized by a very complex and diversified microbiota. Bacteria in the gastrointestinal tract play multiple roles in human health, including metabolic features absent in humans [31], modulation of gut morphology and physiology [32] and development of the immune system [33-35]. Colonization begins at birth, but maturation of the microbiota is a continuous process lasting for several years [36-38].

One of the first facultative organisms to colonize the human gut is E. coli $[39,40]$. There is an ongoing debate on whether diffusely adherent E. coli (DAEC) represent normal inhabitants of the gut or diarrheagenic strains, because many epidemiological studies have shown

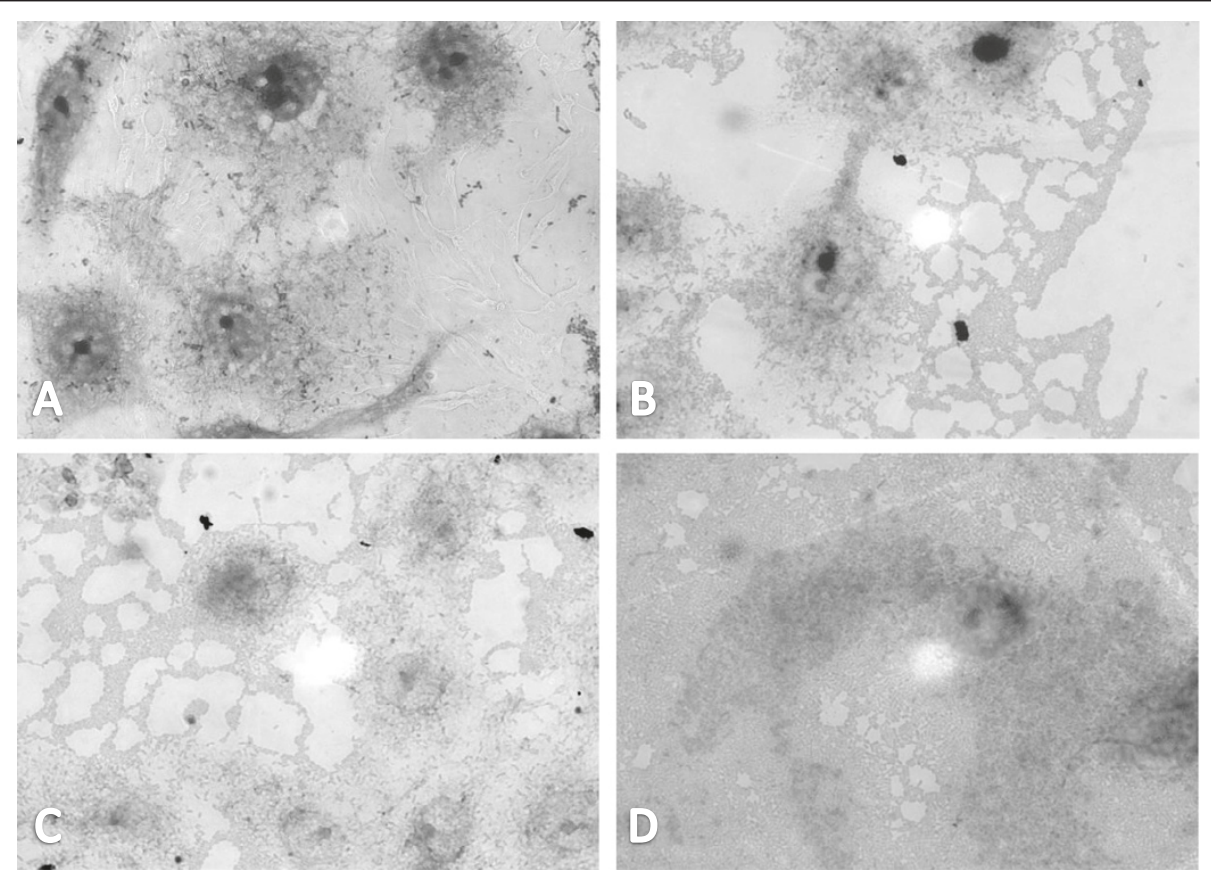

Figure 2 Adhesion of DAEC and C. freundii to HeLa cells. Adherence to HeLa cell monolayers after 3 hours of incubation is intensified when DAEC and $\mathbf{C}$. freundii are inoculated together. $\mathbf{A}$ - typical diffuse adhesion of DAEC strains, when in monoculture; $\mathbf{B}$ - enteroaggregative $\boldsymbol{C}$. freundii showing an aggregative adherence pattern, identical to the aggregative adherence of EAEC strains; $\mathbf{C}, \mathbf{D}$ - adherence assays with cocultures of $\mathbf{C}$. freundii and DAEC. 

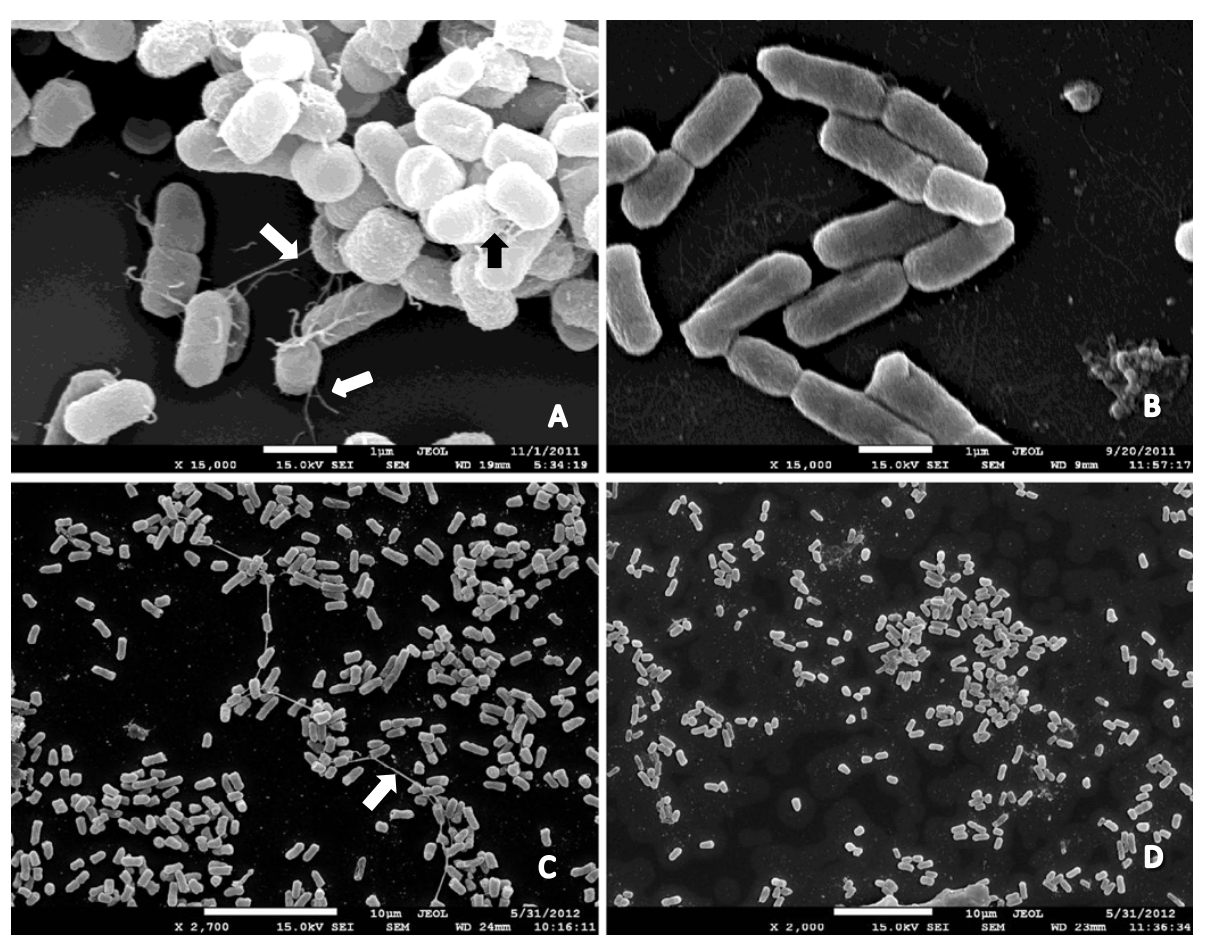

Figure 3 SEM analysis of mixed biofilms. Biofilms inhibited by zinc show thick pili $(\mathbf{A}, \mathbf{C})$ that are not visualized in biofilms insensible to zinc (B D). Pili are seen mediating cell-to-cell interaction and adhesion to surface (white arrows). Fimbrial structures resembling curli can be observed in some samples (black arrows).

inconsistent results $[11,14,41]$. As the controversy has been attributed, at least in part, to an age factor [13-18] we compared DAEC strains belonging to four different groups: children with diarrhea, asymptomatic children, adults with diarrhea and asymptomatic adults.

We have found remarkable differences between strains isolated from adults and from children regarding the characteristics analyzed in this work.

DAEC strains with undetermined afaE were first reported by Zhang et al. [42] that described new variants of Afa/Dr adhesins. In 20\% (30/150) of afaB-C-positive strains in this study, the "E" gene was not identified, and the strains were referred to as "afa-X-positive" strains. In the adult group, $a f a-X$ was only found in strains isolated from cases of diarrhea. This result is similar to that found by Arikawa et al. [25], who reported the presence of undetermined $a f a E$ in $26.3 \%(5 / 19)$ of DAEC strains isolated from cases of diarrhea (which they called " $a f a E X ")$. In contrast, in another work from Japan [43] the authors found $a f a E X$ strains isolated from healthy adults. It is unclear if $a f a-X$ and $a f a E X$ strains harbor the same or different $\mathrm{Afa} / \mathrm{Dr}$ adhesins, since the $a f a E$ gene was not identified. It is likely that there are many yet undescribed variations of $\mathrm{Afa} / \mathrm{Dr}$ adhesins. Korotkova et al. [44] showed that point mutations in $\mathrm{Dr}$ adhesin genes result in phenotypic variability with distinct binding properties. However, in a previous work performed in this laboratory [19] the analysis of surface proteins showed that all $a f a-X$ strains isolated from diarrheic adults had an identical electrophoretic profile, suggesting that all these strains harbor an identical member of Afa/Dr family. Further studies are required to identify Afa-X and clarify its role in the pathogenesis of diarrheas caused by DAEC in adults.

Strains from adults exhibit few types of adhesins in a characteristic pattern: AfaE-V associated with control and the putative Afa/Dr adhesin Afa-X with diarrhea. In contrast, several types of Afa/Dr adhesins are present in strains from children, with no one in particular associated with disease. Great diversity regarding the types of $\mathrm{Afa} / \mathrm{Dr}$ adhesins was especially frequent among strains isolated from asymptomatic children, with $29.3 \%$ of strains harboring more than one Afa/Dr adhesin. The afaE1 and F1845 adhesins are always present in the associations. Both recognize DAF as a receptor, and F1845 also recognizes CEACAMs [2]. Since adhesins are involved in colonization, the presence of related adhesins able to recognize different receptors could provide an adaptive advantage to these bacteria and explain the apparent redundancy of $\mathrm{Afa} / \mathrm{Dr}$ adhesins. Interestingly, DAF expression in erythrocytes is higher in adults than in children [45], being especially low in children aged between 24 and 36 months [46]. If this differential expression were also found in enterocytes, it would help 
explain the advantage of strains from children in presenting adhesins able to bind to receptors other than DAF.

A factor frequently detected in strains isolated from children was the expression of curli. Curli is a bacterial structure involved in the adhesion to both fresh vegetables [47-49] and several proteins widespread in human cells or extracellular matrix, like MHC class I, TLR2, fibronectin and laminin [50]. Most DAEC strains from children that express curli at $37^{\circ} \mathrm{C}$ were also capable of expressing curli at $28^{\circ} \mathrm{C}$ (data not shown). Therefore, curli could facilitate further colonization by $E$. coli ingested through food sources mediating attachment once the bacteria are in the body.

By contrast, curli expression was frequent in strains isolated from diarrheic adults but rare in strains from asymptomatic adults, suggesting a potential involvement with diarrheal disease in adults. Several studies have associated curli to virulence of $E$. coli. Besides being a colonization factor [50], curli leads to the stimulation of inflammatory response in its host [50,51], which is mediated by TLR1/TLR2 [52]. Curli was associated to higher rates of invasion of epithelial cells [53] and increased virulence in mice [54].

Curli shares many characteristics with human amyloids [55]. Amyloid deposits induce chronic inflammation, which in turn results in tissue injuries associated with neurodegenerative diseases, with Alzheimer's disease being the most notorious example. Some lines of evidence suggest that old cells (at least neurons) can be more susceptible to beta-amyloids [56-58]. Analogously, adults could be more susceptible to bacterial amyloids than children, helping to explain why curli might be associated to diarrhea in adults, but not in children. Furthermore, the immune system in children is not fully developed [33], leading us to speculate that while curli expressing $E$. coli strains might be carried by asymptomatic children, healthy adults' immune systems could exclude those potentially virulent strains.

In EPEC strains, the TTSS is part of the the LEE pathogenicity island [3]. Pathogenicity islands (PAIs) are large portions of microbial genomes that are present in pathogens but not in non pathogenic strains of the same species [59]. In this study, genes that are part of the TTSS apparatus were found in strains isolated from asymptomatic children. Despite considering that they were detected too frequently to be found incidentally, we do not know whether these strains possess a functional TTSS. Blanc-Potard et al. [60] found that Afa/Dr DAEC strains C1845 and IH11128 harbor part of a PAI described for an uropathogenic E. coli strain. Analogously, some DAEC strains from children could harbor part of a LEE, including part of a TTSS, but not necessarily the complete functional apparatus. Interestingly,
TTSS genes were found in strains from children, but not in strains from adults. Many strains from children also belong to some classical EPEC serogroup - again not found in strains from adults - leading us to wonder whether the strains from children may be more closely related to EPEC in evolutionary terms. Although TTSS has been associated to virulence in a broad range of Gram-negative bacteria [61], we have found it in control strains. Even though much emphasis has been given to the role of TTSS in pathogenesis, its presence was recorded in non-pathogenic bacteria such as Pseudomonas fluorescens [62] and Sodalis glossinidius [63].

By the late fifties, the development of seroagglutination assays enabled the establishment of the classical groups of EPEC. These serogroup-marked strains were frequently associated with sporadic cases of infantile diarrhea as well as outbreaks [64]. In virtue of the current molecular characterization adopted for typing $E$. coli strains, nowadays it is known that some of the socalled classical EPEC serogroups are shared with other diarrheagenic categories [65-67]. The World Health Organization recognized that EPEC comprises strains of 12 O serogroups known as the classical EPEC serogroups: O26, O55, O86, O111, O114, O119, O125, O126, O127, O128, O142 and O158 [68] In this work, we found $30.5 \%$ of DAEC isolated from children belonging to serogroups O86, O127, O142 or O158. Serogroup O86 was very frequent, corresponding alone to $20 \%$ of DAEC strains isolated from children. This serogroup seems to be widely distributed among different $E$. coli pathotypes, since it has been found in EAEC [65], DAEC [67] and STEC strains [69]. Interestingly, we have not found DAEC strains from adults belonging to EPEC serogroups, reinforcing the differences between DAEC strains isolated from children and adults.

Arikawa et al. [25] found that some DAEC strains are able to stimulate IL-8 secretion by epithelial cells and suggested that strains possessing this ability could be implicated in the establishment of diarrhea. The importance of IL-8 stimulus in the pathogenesis of DAEC strains was reinforced by the study of Meraz et al. [18]. In a more recent work Arikawa et al. [70] found that high levels of IL-8 secretion by epithelial cells were associated with stimulation by flagella via the TLR 5 receptor.

We found some DAEC strains stimulating IL- 8 secretion by HeLa cells. Meanwhile, association with the motility of strains, and consequently to flagella, was not found, perhaps because almost all DAEC strains in this work were mobile. Interestingly, we found more strains able to stimulate IL- 8 secretion cells among strains isolated from asymptomatic children. However, most of DAEC strains stimulated only low levels of IL-8 secretion, which could simultaneously explain the lack of association with diarrhea and the presence of the flagella. 
Developing microbiota in children is not formed by random bacterial groups, but instead consisting of bacterial consortia that interact among themselves [71]. Thus, the chance of a given $E$. coli strain establishing itself will be determined, in large part, by the partners previously found in the gut environment and by the relationships among them. A C. freundii strain (Cf 205) that was shown to be capable of increasing biofilm formation of EAEC strains isolated from cases of diarrhea was selected from a previous study [28]. Since many DAEC strains were not able to form biofilms alone, or only form weak biofilms, we decided to investigate the effect of Cf 205 in DAEC mixed biofilm assays. Consortia DAEC-C. freundii showed not only increased biofilm formation, but also higher adhesion to cultured cells, suggesting that bacterial combinations can be decisive for colonization. A great increase in biofilm formation was observed especially when strains isolated from asymptomatic children were employed in mixed biofilm assays, perhaps because these strains possess greater diversity of adhesins that could help interactions with $C$. freundii. Those strains also showed greater production of cellulose, which is an important component of biofilms, and cellulose could facilitate adherence of bacterial consortia both to abiotic surfaces and cell surfaces.

Other bacterial components possibly involved in formation of mixed biofilms are F pili. It has been demonstrated that the presence of natural conjugative plasmids promotes biofilm formation [29] and that F pili are used in the initial stages of E. coli biofilm formation [30]. We believe that $\mathrm{F}$ pili are involved in mixed biofilms since most of them were inhibited by zinc in a concentration that does not affect bacterial growth. Furthermore, Pereira et al. [28] demonstrated that cell-to-cell interactions involved in EAEC-Cf 205 biofilms were mediated by putative $\mathrm{F}$ pili, leading us to hypothesize that $\mathrm{F}$ pili also mediate DAEC - Cf 205 biofilms.

The effect of a toxin and the resulting association to diarrhea depend on its effective concentration at the site of infection, which in turn depends on the density of producing bacterial cells. Although SAT is highly prevalent in strains from adults, association with diarrhea was found only in strains from children - precisely the strains which showed greater diversity of adhesins, greater expression of cellulose and biofilm formation, in other words, that possess greatest capacity of colonization.

Recent works in the field of microbial ecology that take advantage of non-cultivating methods are elucidating the gut colonization process. Here, we have found that DAEC strains possessing Afa/Dr genes may reflect some principles that apply to the microbiota in general. First, as microbiota composition is different in children and adults, we found that DAEC from children and from adults represent two different populations, with distinct profiles regarding the characteristics studied in this work. Second, as microbiota seems to be more diversified in control subjects than in diarrhea patients [72], DAEC strains isolated from asymptomatic controls present greater diversity of genes related to virulence. Quiroga et al. [73] demonstrated that strains of $E$. coli belonging to four different diarrheagenic categories including DAEC and EPEC - can be found colonizing infants in the first months of life. Here, we refined the analysis of DAEC strains and found that potentially diarrheagenic strains can be found as part of gut microbiota in children. We also demonstrated that many DAEC strains possessing Afa/Dr genes belong to serogroups associated with EPEC, reflecting perhaps an evolutionary relationship.

DAEC strains as etiological agents of diarrhea are still a matter of controversy. We found that DAEC strains possessing Afa/Dr genes from children and adults possibly possess distinct virulent mechanisms. DAEC strains from children apparently have greater ability of colonizing the gastrointestinal tract, which may contribute to the effective action of a toxin, such as SAT. We also demonstrated for the first time, to the authors' knowledge, that curli can play a role in pathogenesis of DAEC strains isolated from adults. Further studies are warranted to conclusively demonstrate this involvement.

\section{Conclusions}

DAEC strains possessing Afa/Dr genes isolated from children and adults have shown very distinct profiles regarding the distribution of the characteristics analyzed in this work. Strains from children are more diverse than strains from adults in relation to the studied characteristics. Most characteristics were more frequent in strains from asymptomatic children. In contrast, virulence factors were less frequent in strains from adults, which seem to form a more homogeneous group. Characteristics potentially associated to virulence are distinct in DAEC strains from adults and children. The results confirm the importance of SAT in diarrhea caused by DAEC in children and suggest that its action may be enhanced as a result of their efficiency in colonization. Moreover, curli is a potential virulence factor for DAEC strains that cause diarrhea in adults. Together, these results indicate that DAEC strains possessing $\mathrm{Afa} / \mathrm{Dr}$ genes isolated from children and adults represent two different bacterial populations. Furthermore, the results also indicate that DAEC strains with virulence markers can be found as part of the normal microbiota present in healthy children.

\section{Methods}

Specimens and strains

Escherichia coli samples belonging to two different collections from this laboratory were used: the first 
consisted of samples isolated from children under 5 years old treated at two hospitals in Brasília, Distrito Federal, Brazil (Hospital Universitário de Brasília and Hospital Materno-Infantil de Brasília). One hundred twenty-seven fecal specimens were collected from patients with diarrhea, along with 127 fecal specimens from healthy children. Control subjects were defined as children who did not present diarrhea in the four-week interval preceeding sample collection. The subjects were matched by age and socioeconomic status within 15 days of sample collection. Subjects who had used antibiotics up to 15 days before sample collection were excluded from the study. Diarrhea was characterized by an increased number of evacuations with loose feces. In general, five $E$. coli strains were isolated from each fecal sample, with a total of 1253 isolates recovered.

The second collection used in this study consists of DAEC strains partially characterized in previous studies $[19,74]$ obtained from 143 cases of diarrhea in adults and from 119 control subjects.

For this study we selected E.coli samples possessing the conserved region of operons $\mathrm{Afa} / \mathrm{Dr}$ ( $\mathrm{afaB} / \mathrm{C}$ genes) and negative for eae - DAEC . All samples were checked for Salmonella and Shigella organisms, in which case they were excluded from the study. Any sample where other E. coli pathovars - EPEC, EAEC, EIEC, ETEC and EHEC/STEC - were recovered were excluded from this study. The samples isolated from children were also checked for rotavirus.

All E. coli strains underwent serological assays for the detection of classical EPEC serogroups O26, O55, O86, O111, O114, O119, O125, O126, O127, O128, O142, O158; EIEC serogroups O28ac, O29, O112ac, O124, O136, O143, O144, O152, O164, O167 and EHEC serogroup O157.

Standard strains of $E$. coli used as control are indicated in Table 5 and were kindly provided by Dr. C. Le Bouguénec and Dr. B. Nowicki. The biofilm-forming aggregative C. freundii (EACF) strain 205 used in mixed biofilms was isolated from a child (aged 13 months) on

Table $\mathbf{5}$ Standard E. coli strains utilized in this work

\begin{tabular}{ll}
\hline Strain & Characteristic \\
\hline C600 & Negative control \\
KS 51 & Operons afa/Dr and afaE-1 \\
A 22 & afaE-2 \\
A 30 & afaE-3 \\
AL 851 & afaE-5 \\
IH 11128 & Dr hemagglutinin \\
C 1845 & F1845/diffuse adhesion \\
042 & Biofilm/ aggregative adhesion \\
17.2 & Biofilm/ aggregative adhesion \\
\hline
\end{tabular}

the fifth day of a mucous diarrhea that presented, on average, 15 evacuations per day, during a case-control study [28].

Bacterial strains were preserved at $-20^{\circ} \mathrm{C}$ in a LuriaBertani broth medium with $15 \%$ glycerol.

\section{Ethics statement}

The study was approved by the University of Brasília's Health Science ethics committee. It was conducted in accordance with guidelines expressed in the Declaration of Helsinki. We sought and obtained individual written informed consent for all subjects; parents or guardians were invited to sign (or thumbprint if illiterate) the informed consent form.

\section{Detection of virulence markers}

Virulence markers were detected by polymerase chain reaction (PCR) performed using the primers listed in Table 6. The cycling conditions for PCR were as follows: 10 cycles at $94^{\circ} \mathrm{C}$ for $1 \mathrm{~min}$, at $55^{\circ} \mathrm{C}$ for $1 \mathrm{~min}$, and at $72^{\circ} \mathrm{C}$ for $90 \mathrm{~s}$, followed by 20 cycles at $94^{\circ} \mathrm{C}$ for $1 \mathrm{~min}$, at $60^{\circ} \mathrm{C}$ for $1 \mathrm{~min}$, and at $72^{\circ} \mathrm{C}$ for $90 \mathrm{~s}$. All target fragments were amplified using similar parameters, except for the annealing temperature. Supernatants derived from bacterial suspension treated by boiling were used as the source of DNA template.

\section{Phenotypic assays}

Tests were performed at $37^{\circ} \mathrm{C}$ to investigate a possible association of curli and cellulose with virulence. Curli production was determined based on colony morphology on CR plates, scored according to the basic morphotypes previously described in S. typhimurium [78] rdar (red colony, expresses curli fimbriae and cellulose), pdar (pink colony, expresses cellulose), bdar (brown colony, expresses curli fimbriae) and saw (white colony, no expression of curli fimbriae nor cellulose). CR plates were grown for $24 \mathrm{~h}$. Cellulose production was determined on plates containing $0.025 \%$ calcofuor. Fluorescent colonies under a $366 \mathrm{~nm}$ UV light source served as an indicator of cellulose production.

The mobility of DAEC strains was determined by the pattern of growth in semi-solid agar.

\section{Biofilm screening assay and zinc inhibition}

In order to screen the biofilm formation by DAEC strains, alone or in association with $C$. freundii 205, 96well flat-bottom polystyrene plates were used [79]. Briefly, $200 \mu \mathrm{L}$ per well of DMEM-mannose were inoculated with $5 \mu \mathrm{L}$ of overnight bacterial culture, and then the plates were incubated overnight at $37^{\circ} \mathrm{C}$ without shaking. Afterwards, the formed biofilms were stained with CV (crystal violet) for $15 \mathrm{~min}$, washed once with $200 \mu \mathrm{L}$ of PBS and air-dried for $3 \mathrm{~h}$. The CV adsorbed 
Table 6 Primers used in polymerase chain reaction analysis

\begin{tabular}{|c|c|c|c|c|c|}
\hline Gene & Locus description & Primer sequence & Fragment length & Annealing temperature & Reference \\
\hline \multirow[t]{2}{*}{$a f a \mathrm{~B}-\mathrm{C}$} & \multirow{2}{*}{$\begin{array}{l}\text { Conserved region of } \\
\text { Afa/Dr operons }\end{array}$} & 5' CTGGGCAGCAAACTGATAACTCTC 3' & \multirow[t]{2}{*}{$750 \mathrm{pb}$} & \multirow[t]{2}{*}{$62^{\circ} \mathrm{C}$} & \multirow[t]{2}{*}{ [75] } \\
\hline & & 5' CATCAAGCTGTTTGTTCGTCCGCCG 3' & & & \\
\hline \multirow[t]{2}{*}{$a f a E-1$} & \multirow[t]{2}{*}{ Afa-l afimbrial adhesin } & 5' CGAAAACGGCACTGACAAG 3' & \multirow[t]{2}{*}{$230 \mathrm{pb}$} & \multirow[t]{2}{*}{$61^{\circ} \mathrm{C}$} & \multirow[t]{2}{*}{ [19] } \\
\hline & & 5' AGGCTTCCGTGAATACAACC 3' & & & \\
\hline \multirow[t]{2}{*}{$a f a E-2$} & \multirow[t]{2}{*}{ Afa-Il afimbrial adhesin } & $5^{\prime}$ TTAGACCGTACTGTTGTGTTACC 3 & \multirow[t]{2}{*}{$375 \mathrm{pb}$} & \multirow[t]{2}{*}{$48^{\circ} \mathrm{C}$} & \multirow[t]{2}{*}[42]{} \\
\hline & & 5’ TाTCCCAGTAGACTGGAATGAAGC 3' & & & \\
\hline \multirow[t]{2}{*}{ afaE-3/dre } & \multirow{2}{*}{$\begin{array}{l}\text { Afa-III afimbrial adhesin/ } \\
\text { Dr afimbrial adhesin }\end{array}$} & $5^{\prime}$ TTAGACCGTACTGTTGTGTACC $3^{\prime}$ & \multirow[t]{2}{*}{$408 \mathrm{pb}$} & \multirow[t]{2}{*}{$65^{\circ} \mathrm{C}$} & \multirow[t]{2}{*}{ [76] } \\
\hline & & 5' ACCATTGTCGGTCGTCCAGGC 3' & & & \\
\hline \multirow[t]{2}{*}{$a f a E-5$} & \multirow[t]{2}{*}{ Afa- $V$ afimbrial adhesin } & 5' TTAGACCGTACTGTTGTGTTACC ' & \multirow[t]{2}{*}{$429 \mathrm{pb}$} & \multirow[t]{2}{*}{$48^{\circ} \mathrm{C}$} & \multirow[t]{2}{*}{ [42] } \\
\hline & & 5' AGCATCGGCGCGGTATACGGT 3' & & & \\
\hline \multirow[t]{2}{*}{ daaE } & \multirow[t]{2}{*}{ F1845 fimbrial adhesin } & 5' TGACTGTGACCGAAGAGTGC 3' & \multirow[t]{2}{*}{$380 \mathrm{pb}$} & \multirow[t]{2}{*}{$48^{\circ}$} & \multirow[t]{2}{*}[19]{} \\
\hline & & $5^{\prime}$ TTAGTTCGTCCAGTAACCCCC 3' & & & \\
\hline \multirow[t]{2}{*}{ Sat } & \multirow[t]{2}{*}{ Secreted auto transported toxin } & 5' GCAGCAAATATTGATATATCA 3' & \multirow[t]{2}{*}{$630 \mathrm{pb}$} & \multirow[t]{2}{*}{$57^{\circ} \mathrm{C}$} & \multirow[t]{2}{*}{ [21] } \\
\hline & & 5' GTTGTTGACCTCAGCCAAGGAA 3' & & & \\
\hline escJ & Type Three Secretion System & 5' CACTAAGCTCGATATATAGAACCC 3' & $826 \mathrm{pb}$ & $54^{\circ} \mathrm{C}$ & [20] \\
\hline & & 5' GTCAATGTTGATGTCGTATCTAAG 3' & & & \\
\hline escV & Type Three Secretion System & 5' GATGACATCATGAATAAACTC 3' & $2130 \mathrm{pb}$ & $54^{\circ} \mathrm{C}$ & [20] \\
\hline & & 5' GCCTTCATATCTGGTAGAC 3' & & & \\
\hline $\operatorname{traA}$ & Pilin & 5' AAGTGTTCAGGGTGCTTCTG 3' & $385 \mathrm{pb}$ & $60^{\circ} \mathrm{C}$ & [28] \\
\hline & & 5' TATTCTCGTCTCCCGACATC 3' & & & \\
\hline eae & intimin & 5' CCCGAATTCGGCACAAGCATAAGC 3' & $881 \mathrm{pb}$ & $52^{\circ} \mathrm{C}$ & [77] \\
\hline & & 5' CCCGGATCCGTCTCGCCAGTATTCG3' & & & \\
\hline
\end{tabular}

on the well bottom and the bacterium-bound dye were released by the addition of ethanol $(200 \mu \mathrm{L} /$ well $)$ and the absorbance (OD at $630 \mathrm{~nm}$ ) was measured. The mean of the absorbances of three independent tests was used as the measure for the formed biofilms. The ability of DAEC strains to form biofilms on abiotic surfaces was assessed by comparison with standard strains that form biofilm (EAEC strain 042 and Cf 205) and a non biofilm forming strain (C600). The Citrobacter freundii strain 205 (Cf 205), isolated from a diarrheic child in Brasilia, Brazil [28], was added to controls because it had been used in mixed biofilms assays. Biofilms where divided in two groups according to the optical density comparing to controls. They were considered weak when their OD was within $20 \%$ of the Cf205 strain's; and strong when the OD was greater than that. When the OD was found to be within $20 \%$ of the C600 strain's, it was considered that there was no biofilm formation.

Assays focusing on biofilm inhibition were conducted in the same way using DMEM-mannose containing $\mathrm{ZnSO} 4$ at a concentration of $0.25 \mathrm{mM}-12$ times lower than the minimum inhibitory concentration (MIC) for zinc [28].

\section{HeLa cells and infection assays}

HeLa cells were cultured in DMEM (Dubelco's modified Eagle,s medium; Gibco, BRL) with 5\% fetal bovine serum and antibiotics $(120 \mu \mathrm{g} / \mathrm{mL}$ ampicillin and $100 \mu \mathrm{g} / \mathrm{mL}$ streptomycin) at $4 \% \mathrm{CO}_{2}$ and $37^{\circ} \mathrm{C}$. For qualitative infection assays (adhesion tests), HeLa cells $\left(0.6 \times 10^{5}\right.$ cells/ $\mathrm{mL}$ ) were cultured on glass coverslips using 24-well culture plates $(600 \mu \mathrm{L} /$ well) (Costar). Cells were grown to $50 \%-70 \%$ confluence, and the medium was changed to DMEM supplemented with $1 \%$ mannose (DMEM-mannose) without FBS. For adhesion assays, HeLa cells were infected with $50 \mu \mathrm{L}$ of an overnight bacterial culture (OD 0.6 at $600 \mathrm{~nm}$ ) for three hours at $37^{\circ} \mathrm{C}$. For mixed infection assays $25 \mu \mathrm{L}$ of each culture were used. After infection, the coverslips were washed five times with Dulbecco's PBS (D-PBS). The cells were then fixed with methanol, stained with May-Grünwald and Giemsa stains, and analyzed using light microscopy. DAEC prototype strain C1845 was used as the positive control for the diffuse adhesion phenotype.

\section{IL-8 secretion}

In order to detect IL-8 secretion, after $24 \mathrm{~h}$ of epithelial cell infection, cell-free culture supernatants were tested 
in triplicate for this cytokine by enzyme-linked immunosorbent assay using a commercial kit (eBioscience), as recommended by the manufacturer. Samples were considered positive when amounts of IL- 8 greater than 10 $\mathrm{pg} / \mathrm{mL}$ were detected. Non-infected HeLa cells and cells infected with E. coli $\mathrm{C} 600$ were used as negative controls.

\section{Scanning electron microscopy (SEM)}

For SEM observations, samples were processed following standard protocols. In summary, the samples were fixed overnight at $4{ }^{\circ} \mathrm{C}$ in Karnovsky's solution (2.5\%. paraformaldehyde, $2 \%$ glutaraldehyde in $0.1 \mathrm{M}$ cacodylate buffer, $\mathrm{pH}$ 7.4) and then post-fixed with $0.1 \mathrm{M}$ cacodylate buffer ( $\mathrm{pH}$ 7.4) containing osmium tetroxide (1\%) and potassium ferricyanide $(0.8 \%)$ for $1 \mathrm{~h}$ at room temperature. Afterwards, the samples were dehydrated in a graded acetone series (30-100\%), dried at critical point using $\mathrm{CO} 2$ as the transition fluid, and sputter-coated with gold (2 min).

\section{Statistical analysis}

Results were analyzed using the $t$ test, chi-square, or Fisher's exact tests, using the most appropriate test for each sample. Results with $\mathrm{p}$-values $\leq 0.05$ were considered to be statistically significant.

\section{Competing interests}

The authors declare that they have no competing interests.

\section{Authors' contributions}

RMA conceived the study and designed the experiments. RMA, ALP and LGG analyzed the data, wrote the manuscript and were responsible for concepts, vision and direction for the study. All authors read and approved the final manuscript.

\section{Acknowledgements}

The authors would like to thank Dr Sonia Nair Bao and the team of Laboratório de Microscopia, UnB, and Dr Andréa Maranhão, Laboratório de Biologia Molecular, UnB, for the technical assistance. We are very grateful to Dr Robert Miller for the manuscript review. This work was supported by research grant 2010/00188-1 from FAPDF.

Received: 5 September 2012 Accepted: 16 January 2013

Published: 1 February 2013

\section{References}

1. Dobrindt U: (Patho-) genomics of escherichia coli. Int J Med Microbiol 2005, 295:357-371.

2. Servin AL: Pathogenesis of Afa/Dr diffusely adhering Escherichia coli. Clin Microbiol Rev 2005, 18:264-292.

3. Kaper JB, Nataro JP, Mobley H: Pathogenic escherichia coli. Nat Rev Microbiol 2004, 2:123-140.

4. Germani Y, Bégaud E, Duval P, Le Bouguénec C: Prevalence of enteropathogenic, enteroaggregative, and diffusely adherent Escherichia coli among isolates from children with diarrhea in new Caledonia. $J$ Infect Dis 1996, 174:1124-1126.

5. Le Bouguenec C, Servin AL: Diffusely adherent escherichia coli strains expressing Afa/Dr adhesins (Afa/Dr DAEC): hitherto unrecognized pathogens. FEMS Microbiol Lett 2006, 256:185-194.

6. Guignot J, Peiffer I, Bernet-Camard MF, Lublin DM, Carnoy C, Moseley SL, Servin AL: Recruitment of CD55 and CD66e brush border-associated glycosylphosphatidylinositol-anchored proteins by members of the Afa/
Dr diffusely adhering family of Escherichia coli that infect the human polarized intestinal Caco-2/TC7 cells. Infect Immun 2000, 68:3554-3563.

7. Berger CN, Billker O, Meyer TF, Servin AL, Kansau I: Differential recognition of members of the carcinoembryonic antigen family by Afa/Dr adhesins of diffusely adhering Escherichia coli (Afa/Dr DAEC). Mol Microbiol 2004, 52:963-983.

8. Bernet-Camard MF, Coconnier MH, Hudault S, Servin AL: Pathogenicity of the diffusely adhering strain Escherichia coli C1845: F1845 adhesindecay accelerating factor interaction, brush border microvillus injury, and actin disassembly in cultured human intestinal epithelial cells. Infect Immun 1996, 64:1918-1928.

9. Peiffer I, Guignot J, Barbat A, Carnoy C, Moseley SL, Nowicki BJ, Servin AL, Bernet-Camard MF: Structural and functional lesions in brush border of human polarized intestinal Caco-2/TC7 cells infected by members of the Afa/Dr diffusely adhering family of Escherichia coli. Infect Immun 2000, 68:5979-5990

10. Goluszko P, Selvarangan R, Popov V, Pham T, Wen JW, Singhal J: Decayaccelerating factor and cytoskeleton redistribution pattern in HeLa cells infected with recombinant Escherichia coli strains expressing Dr family of adhesins. Infect Immun 1999, 67:3989-3997.

11. Albert MJ, Faruque AS, Faruque SM, Sack RB, Mahalanabis D: Case-control study of enteropathogens associated with childhood diarrhea in Dhaka. Bangladesh. J Clin Microbiol 1999, 37:3458-3464.

12. Rajendran P, Ajjampur SS, Chidambaram D, Chandrabose G, Thangaraj B, Sarkar R, Samuel P, Rajan DP, Kang G: Pathotypes of

diarrheagenicscherichia coli in children attending a tertiary care hospital in South India. Diagn Microbiol Infect Dis 2010, 68:117-122.

13. Scaletsky IC, Fabricotti SH, Carvalho RLB, Nunes CR, Morais MB, FagundesNeto U: Diffusely adherent Escherichia coli as a cause of acute diarrhea in young children in northeast Brazil: a case-control study. J Clin Microbiol 2002, 40:645-646.

14. Opintan JA, Bishar RA, Newman MJ, Okeke IN: Carriage of diarrhoeagenic Escherichia coli by older children and adults in Accra, Ghana. Trans R SOC Trop Med Hyg 2010, 104:504-506.

15. Ochoa TJ, Ecker L, Barletta F, Mispireta ML, Gil Al, Contreras C, Molina M, Amemiya I, Verastegui H, Hall ER, Cleary TG, Lanata CF: Age-related susceptibility to infection with diarrheagenic Escherichia coli among infants from Periurban areas in Lima. Peru. Clin Infect Dis 2009, 11:1694-1702.

16. Gunzburg ST, Chang BJ, Elliot SJ, Burke V, Gracey M: Diffuse and enteroaggregative patterns of adherence of enteric Escherichia coli isolated from aboriginal children from the Kimberley region of Western Australia. J Infect Dis 1993, 167:755-758.

17. Levine MM, Ferreccio C, Prado V, Cayazzo M, Abrego P, Martinez J, Maggi L, Baldini MM, Martin W, Maneval D: Epidemiologic studies of Escherichia coli diarrheal infections in a low socioeconomic level peri-urban community in Santiago. Chile. Am J Epidemiol 1993, 138:849-869.

18. Meraz IM, Arikawa K, Nakamura H, Ogasawara J, Hase A, Nishikawa Y Association of IL-8-inducing strains of diffusely adherent Escherichia coli with sporadic diarrheal patients with less than 5 years of age. Braz J Infect Dis 2007, 11:44-49.

19. Almeida RM: Escherichia coli de adesão difusa (DAEC) isoladas de infecções entéricas: prevalência e caracterização de adesinas da família Afa/Dr, Dissertação de mestrado. Brasília, DF: Universidade de Brasília, Faculdade de Ciências da Saúde; 2003.

20. Kyaw CM, De Araujo CR, Lima MR, Gondim EG, Brígido MM, Giugliano LG: Evidence for the presence of a type III secretion system in diffusely adhering Escherichia coli (DAEC). Infect Genet Evol 2003, 3:111-117.

21. Taddei CR, Moreno AC, Fernandes Filho A, Montemor LP, Martinez MP. Prevalence of secreted autotransporter toxin gene among diffusely adhering Escherichia coli isolated from stools of children. FEMS Microbiol Lett 2003, 227:249-253.

22. Guignot J, Chaplais C, Coconnier-Polter MH, Servin AL: The secreted autotransporter toxin, Sat, functions as a virulence factor in Afa/Dr diffusely adhering Escherichia coli by promoting lesions in tight junction of polarized epithelial cells. Cell Microbiol 2007, 9:204-221.

23. Betis F, Brest P, Hofman V, Guignot J, Kansau I, Rossi B, Servin A, Hofman P: Afa/Dr diffusely adhering Escherichia coli infection in T84 cell monolayers induces increased neutrophil transepithelial migration, which in turn promotes cytokine-dependent upregulation of decayaccelerating factor (CD55), the receptor for Afa/Dr adhesins. Infect Immun 2003, 71:1774-1783. 
24. Brest $P$, Betis $F$, Cuburu N, Selva E, Herrant $M$, Servin A, Auberger $P$, Hofman $P$ : Increased rate of apoptosis and diminished phagocytic ability of human neutrophils infected with Afa/Dr diffusely adhering Escherichia coli strains. Infect Immun 2004, 72:5741-5749.

25. Arikawa K, Meraz IM, Nishikawa Y, Ogasawara J, Hase A: Interleukin-8 secretion by epithelial cells infected with diffusely adherent Escherichia coli possessing Afa adhesin-coding genes. Microbiol Immunol 2005, 49:493-503.

26. Weiss-Muszkat M, Shakh D, Zhou Y, Pinto R, Belausov E, Chapman MR, Sela S: Biofilm formation by and multicellular behavior of Escherichia coli O55:H7, an atypical enteropathogenic strain. Appl Environ Microbiol 2010, 76:1545-1554.

27. Huang DB, Dupont HL: Enteroaggregative Escherichia coli: an emerging pathogen in children. Semin Pediatr Infect Dis 2004, 15:266-271.

28. Pereira AL, Silva TN, Gomes AC, Araújo AC, Giugliano LG: Diarrheaassociated biofilm formed by enteroaggregative Escherichia coli and aggregative Citrobacter freundii: a consortium mediated by putative $\mathrm{F}$ pili. BMC Microbiol 2010, 10:57.

29. Ghigo JM: Natural conjugative plasmids induce bacterial biofilm development. Nature 2001, 412:442-445.

30. May T, Okabe S: Escherichia coli harboring a natural IncF conjugative $F$ plasmid develops complex mature biofilms by stimulating synthesis of colanic acid and Curli. J Bacterio/ 2008, 190:7479-7490.

31. Bäckhed F, Ley RE, Sonnenburg JL, Peterson DA, Gordon Jl: Host-bacterial mutualism in the human intestine. Science 2005, 307:1915-1920.

32. Chowdhury SR, King DE, Willing BP, Band MR, Beever JE, Lane AB, Loor JJ, Marini JC, Rund LA, Schook LB, Van Kessel AG, Gaskins HR: Transcriptome profiling of the small intestinal epithelium in germfree versus conventional piglets. BMC Genomics 2007, 8:215.

33. Kelly D, King T, Aminov R: Importance of microbial colonization of the gut in early life to the development of immunity. Mutat Res 2007, 622:58-69.

34. Heavey PM, Rowland IR: Microbial-gut interactions in health and disease. Gastrointestinal cancer. Best Pract Res Clin Gastroenterol 2004, 18:323-336.

35. Björkstén B, Sepp E, Julge K, Voor T, Mikelsaar M: Allergy development and the intestinal microflora during the first year of life. J Allergy Clin Immunol 2001, 108:516-520

36. Yatsunenko T, Rey FE, Manary MJ, Trehan I, Dominguez-Bello MG, Contreras M, Magris M, Hidalgo G, Baldassano RN, Anokhin AP, Heath AC, Warner B, Reeder J, Kuczynski J, Caporaso JG, Lozupone CA, Lauber C, Clemente JC, Knights D, Knight R, Gordon J: Human gut microbiome viewed across age and geography. Nature 2012, 486:222-227.

37. Palmer C, Bik EM, DiGiulio DB, Relman DA, Brown PO: Development of the human infant intestinal microbiota. PLoS Biol 2007, 5:e177.

38. Agans R, Rigsbee L, Kenche H, Michail S, Khamis HJ, Paliy O: Distal gut microbiota of adolescent children is different from that of adults. FEMS Microbiol Ecol 2011, 77:404-412.

39. Eggesbø M, Moen B, Peddada S, Baird D, Rugtveit J, Midtvedt T, Bushel PR, Sekelja M, Rudi K: Development of gut microbiota in infants not exposed to medical interventions. APMIS 2011, 119:17-35.

40. Brandt K, Taddei CR, Takagi EH, Oliveira FF, Duarte RT, Irino I, Martinez $\mathrm{MB}$, Carneiro-Sampaio M: Establishment of the bacterial fecal community during the first month of life in Brazilian newborns. Clinics 2012, 67:113-123.

41. Guion CE, Ochoa TJ, Walker CM, Barletta F, Cleary TG: Detection of diarrheagenic Escherichia coli by use of melting-curve analysis and realtime multiplex PCR. J Clin Microbiol 2008, 46:1752-1757.

42. Zhang L, Foxman B, Tallman P, Cladera E, Le Bouguenec C, Marrs CF: Distribuiton of drb genes coding for Dr binding adhesins among uropathogenic and fecal Escherichia coli isolates and identification of new subtypes. Infect Immun 1997, 65:2011-2018.

43. Fujihara S, Arikawa K, Aota T, Tanaka H, Nakamura H, Wada T, Hase A, Nishikawa Y: Prevalence and properties of diarrheagenic Escherichia coli among healthy individuals in Osaka City. Japan. Jpn J Infect Dis 2009, 62:318-323.

44. Korotkova N, Chattopadhyay S, Tabata TA, Beskhlebnaya V, Vigdorovich V, Kaiser BK, Strong RK, Dykhuizen DE, Sokurenko EV, Moseley SL: Selection for functional diversity drives accumulation of point mutations in $\mathrm{Dr}$ adhesins of Escherichia coli. Mol Microbiol 2007, 64:180-194.

45. Waitumbi JN, Donvito B, Kisserli A, Cohen JH, Stoute JA: Age-related changes in red blood cell complement regulatory proteins and susceptibility to severe malaria. J Infect Dis 2004, 190:1183-1191.
46. Odhiambo CO, Otieno W, Adhiambo C, Odera MM, Stoute JA: Increased deposition of $\mathrm{C} 3 \mathrm{~b}$ on red cells with low CR1 and CD55 in a malariaendemic region of western Kenya: implications for the development of severe anemia. BMC Med 2008, 6:23.

47. Berger CN, Sodha SV, Shaw RK, Griffin PM, Pink D, Hand P, Frankel G: Fresh fruit and vegetables as vehicles for the transmission of human pathogens. Viron Microbiol 2010, 12:2385-2397.

48. Shaw RK, Berger CN, Feys B, Knutton S, Pallen MJ, Frankel G Enterohemorrhagic Escherichia coli exploits EspA filaments for attachment to salad leaves. Appl Environ Microbiol 2008, 74:2908-2914.

49. Boyer RR, Sumner SS, Williams RC, Pierson MD, Popham DL, Kniel KE: Influence of curli expression by Escherichia coli 0157:H7 on the cell's overall hydrophobicity, charge, and ability to attach to lettuce. J Food Prot 2007, 70:1339-1345.

50. Barnhart MM, Chapman MR: Curli biogenesis and function. Annu Rev Microbiol 2006, 60:131-147

51. Bian Z, Brauner A, Li Y, Normark S: Expression of and cytokine activation by Escherichia coli curli fibers in human sepsis. J Infect Dis 2000, 181:602-612.

52. Tükel C, Wilson RP, Nishimori JH, Pezeshki M, Chromy BA, Bäumler AJ: Responses to amyloids of microbial and host origin are mediated through toll-like receptor 2. Cell Host Microbe 2009, 6:45-53.

53. Gophna U, Barlev M, Seijffers R, Oelschlager TA, Hacker J, Ron EZ: Curli fibers mediate internalization of Escherichia coli by eukaryotic cells. Infect Immun 2001, 69:2659-2665.

54. Uhlich GA, Keen JE, Elder RO: Variations in the csgD promoter of Escherichia coli 0157:H7 associated with increased virulence in mice and increased invasion of HEp-2 cells. Infect Immun 2002, 70:395-399.

55. Chapman MR, Robinson LS, Pinkner JS, Roth R, Heuser J, Hammar M, Normark S, Hultgren SJ: Role of Escherichia coli curli operons in directing amyloid fiber formation. Science 2002, 295:851-855.

56. Brewer GJ: Age-related toxicity to lactate, glutamate, and beta-amyloid in cultured adult neurons. Neurobiol Aging 1998, 19:561-568.

57. Patel JR, Brewer GJ: Age-related changes to tumor necrosis factor receptors affect neuron survival in the presence of beta-amyloid. J Neurosci Res 2008, 86:2303-2313.

58. Brewer GJ, Lim A, Capps NG, Torricelli JR: Age-related calcium changes, oxyradical damage, caspase activation and nuclear condensation in hippocampal neurons in response to glutamate and beta-amyloid. Exp Gerontol 2005, 40:426-437.

59. Morschhäuser J, Köhler G, Ziebuhr W, Blum-Oehler G, Dobrindt U, Hacker J: Evolution of microbial pathogens. Philos Trans R Soc Lond B Biol Sci 2000, 29(355):695-704

60. Blanc-Potard AB, Tinsley C, Scaletsky I, Le Bouguenec C, Guignot J, Servin AL, Nassif X, Bernet-Camard M: Representational difference analysis between Afa/Dr diffusely adhering Escherichia coli and nonpathogenic E. coli K-12. Infect Immun 2002, 70:5503-5511.

61. Tampakaki AP, Fadouloglou VE, Gazi AD, Panopoulos NJ, Kokkinidis M: Conserved features of type III secretion. Cell Microbiol 2004, 6:805-816.

62. Preston GM, Bertrand N, Rainey PB: Type III secretion in plant growthpromoting Pseudomonas fluorescens SBW25. Mol Microbiol 2001, 41:999-1014.

63. Dale C, Young SA, Haydon DT, Welburn SC: The insect endosymbiont Sodalis glossinidius utilizes a type III secretion system for cell invasion. Proc Natl Acad Sci USA 2001, 98:1883-1888.

64. Levine MM, Nataro JP, Karch H, Baldini MM, Kaper JB, Black RE, Clements $\mathrm{ML}$, O'Brien AD: The diarrheal response of humans to some classic serotypes of enteropathogenic Escherichia coli is dependent on a plasmid encoding an enteroadhesiveness factor. J Infect Dis 1985, 152:550-559.

65. Pereira AL, Ferraz LR, Silva RS, Giugliano LG: Enteroaggregative Escherichia coli virulence markers: positive association with distinct clinical characteristics and segregation into 3 enteropathogenic E. coli serogroups. J Infect Dis 2007, 195:366-374.

66. Campos LC, Franzolin MR, Trabulsi LR: Diarrheagenic Escherichia coli categories among the traditional enteropathogenic E. coli O serogroups - a review. Mem Inst Oswaldo Cruz 2004, 99:545-552.

67. Paciorek J: Virulence properties of Escherichia coli faecal strains isolated in Poland from healthy children and strains belonging to serogroups 018, 026, 044, 086, 0126 and 0127 isolated from children with diarrhoea. J Med Microbiol 2002, 51:548-556. 
68. WHO: Programme for Control of Diarrhoeal Diseases, Manual for laboratory investigations of acute enteric infections. Geneva: World Health Organization; 1987.

69. Sang WK, Boga HI, Waiyaki PG, Schnabel D, Wamae NC, Kariuki SM: Prevalence and genetic characteristics of Shigatoxigenic Escherichia coli from patients with diarrhoea in Maasailand. Kenya. J Infect Dev Ctries 2012 6:102-108.

70. Arikawa K, Nishikawa Y: Interleukin-8 induction due to diffusely adherent Escherichia coli possessing Afa/Dr genes depends on flagella and epithelial Toll-like receptor 5. Microbiol Immunol 2010, 54:491-501.

71. Koenig JE, Spor A, Scalfone N, Fricker AD, Stombaugh J, Knight R, Angenent LT, Ley RE: Succession of microbial consortia in the developing infant gut microbiome. Proc Natl Acad Sci USA 2011, 108(Suppl 1):4578-4585.

72. Mai V, Braden CR, Heckendorf J, Pironis B, Hirshon JM: Monitoring of stool microbiota in subjects with diarrhea indicates distortions in composition. J Clin Microbiol 2006, 44:4550-4552.

73. Quiroga M, Oviedo P, Chinen I, Pegels E, Husulak E, Binztein N, Rivas M, Schiavoni L, Vergara M: Asymptomatic infections by diarrheagenic. Rev Inst Med Trop Sao Paulo 2000, 42:9-15.

74. Piva IC: Incidência e caracterização de Escherichia coli diarreiogênica isolada em Brasilia, Dissertação de mestrado. Brasília, DF: Universidade de Brasília, Departamento de Biologia Celular; 1998.

75. Le Bouguenec C, Archambaud M, Labigne A: Rapid and specific detection of the pap, afa, and sfa adhesin-encoding operons in uropathogenic Escherichia coli strains by polymerase chain reaction. J Clin Microbiol 1992, 30:1189-1193.

76. Le Bouguenec C, Garcia MI, Ouin AV, Desperrier JM, Gounon P, Labigne A: Characterization of plasmid-borne afa-3 gene clusters encoding afimbrial adhesins expressed by Escherichia coli strains associated with intestinal or urinary tract infections. Infect Immun 1993, 61:5106-5114.

77. Oswald E, Schmidt H, Morabito S, Karch H, Marchès O, Caprioli A: Typing of intimin genes in human and animal enterohemorrhagic and enteropathogenic Escherichia coli: characterization of a new intimin variant. Infect Immun 2000, 68:64-71.

78. Römling U, Rohde M, Olsén A, Normark S, Reinköster J: AgfD, the checkpoint of multicellular and aggregative behaviour in Salmonella typhimurium regulates at least two independent pathways. Mol Microbiol 2000, 36:10-23.

79. Wakimoto N, Nishi J, Sheikh J, Nataro JP, Sarantuya J, Iwashita M, Manago K, Tokuda K, Yoshinaga M, Kawano Y: Quantitative biofilm assay using a microtiter plate to screen for enteroaggregative Escherichia coli. Am J Trop Med Hyg 2004, 71:687-690.

doi:10.1186/1471-2180-13-22

Cite this article as: Mansan-Almeida et al.: Diffusely adherent Escherichia coli strains isolated from children and adults constitute two different populations. BMC Microbiology 2013 13:22.

\section{Submit your next manuscript to BioMed Central and take full advantage of:}

- Convenient online submission

- Thorough peer review

- No space constraints or color figure charges

- Immediate publication on acceptance

- Inclusion in PubMed, CAS, Scopus and Google Scholar

- Research which is freely available for redistribution 